Religion and Gender, vol. 2, no. 2 (2012), pp.

254-279

www.religionandgender.org

URN:NBN:NL:UI:10-1-101604

ISSN: $1878-5417$

Publisher: Igitur Publishing (Utrecht)

Copyright: this work is licensed under a Creative

Commons Attribution License (3.0)

\title{
Masculinity, Homosexuality and the Defence of Islam: A Case Study of Yusuf al-Qaradawi's Media Fatwa
}

\author{
SCOTt Kugle AND StePHEN HUNT
}

\begin{abstract}
This paper analyses how Islamic Neo-traditionalists perceive gender constructs through a distorted view of religious texts and cultural conventions. It explores the ramifications of these constructs for attitudes towards same-sex orientations and relationships. These themes are discussed with reference to a case study of a TV talk show on 5 June 2006 by one conservative scholar-activist, Shaykh Yusuf alQaradawi, whose teachings have an impact in the Middle-East and on Muslim minorities in the West. The paper will demonstrate how al-Qaradawi articulates his views of homophobia as part of an agenda to reinforce perceived threats to Muslim masculinity.
\end{abstract}

\section{Keywords}

Homophobia, Islam, masculinities, media, Neo-traditionalism

\section{Author affiliation}

Scott Kugle is a scholar in comparative religion and Islamic culture. He serves as Associate Professor in Middle Eastern and South Asian Studies at Emory University, Atlanta. He has conducted research in South Asia and the Arab World 
focusing on Islamic discourse, gender and devotional music and literature in Urdu, Persian and Arabic. Email: skugle@emory.edu

Stephen Hunt is a scholar of sociology and religion. He serves as Associate Professor of Sociology at the University of the West of England and has also taught in departments of religion. His research interests include contemporary religious movements and debates about sexual minorities in Christian Churches. Email: Stephen3.Hunt@uwe.ac.uk

\section{Introduction}

There is overwhelming historical evidence suggesting that patriarchy-based societies tend to inflect their religious beliefs and symbols not only to justify social inequality but also to express a deep-seated homophobia. This article posits that neither gender inequalities nor homophobia are intrinsic to Islam. As some scholars have persuasively argued, Islam was forced to compromise with patriarchal social structures from an early period and has been interpreted as fully patriarchal in its 'classical era'. ${ }^{1}$ The Arab culture which first forged Islam as a new religion was patriarchal, while Mesopotamian, Iranian, Egyptian and Hellenic cultures were also patriarchal before rapidly being absorbed into Islamic civilization resulting from Arab conquest in the eighth century CE. Subsequently, as Leila Ahmed has argued, the classical tradition of Islamic theology and jurisprudence was constructed and implemented by male authorities. ${ }^{2}$

Contemporary Muslim communities are displaying heightened tension over issues of homophobia and patriarchy, as Islamic feminists, constitutionalists (progressives), and human rights activists question traditional norms within their communities. Western domination and the demise of post-colonial authoritarian regimes have added force to these reformist critiques of patriarchal power structures. In reaction, some Muslim authorities voice a 'Neo-traditional' Islamic ideology, seeking to 'defend' Islam against these challenges. Neo-traditionalists clearly seek popular support via discourses of conventional masculinity deemed as natural, traditional, moral and politically necessary to protect Muslim communities against Western domination. This article will examine how Neo-traditionalists express such positions through a case study which

1 Cf. As'ad AbuKhalil, 'Gender Boundaries and Sexual Categories in the Arab World', in Feminist Issues, 15:1/2 (1979), 91-104; Everett Rowson, 'Categorising Gender and Sexual Irregularity in Medieval Arabic Vice Lists' in J. Epstein and K. Staub (eds.), Body Guards: The Cultural Politics of Gender Ambiguity, New York: Routledge 1991, 50-79.

2 Leila Ahmed, Women and Gender in Islam, New Haven: Yale University Press 1992. 
analyses a TV talk show on 5 June 2006 by one conservative scholaractivist, Shaykh Yusuf al-Qaradawi, who is popular in the Arab world and influential among Muslim minorities in the Western world. The article will demonstrate how al-Qaradawi articulates his views of homophobia as part of an agenda to reinforce perceived threats to Muslim masculinity. The article further challenges al-Qaradawi from a progressive Islamic viewpoint supported by Scott Kugle's expertise as a progressive Muslim scholar. ${ }^{3}$ The challenge is refined by Stephen Hunt's critical view as a sociologist interested in how religious communities react to sexuality and gender minorities in their midst. ${ }^{4}$

\section{Masculinity and Homosexuality}

Masculinity is not self-evident and self-sustaining. Its status is supported and reinforced by bodily comportment where the 'inviolable' male body is properly conceived as a masculinized body - invulnerable, non-porous, clearly bounded, and not accepting penetration compared to the feminized body conceived as vulnerable, porous, un-bounded and accepting penetration. What permeates the male body compromises it, highlighting dependency and vulnerability. In psychoanalytic terms 'subjection' denotes an ego asserting its subject position: that is has a name, form and power. Such an assertive process of 'subjectivization' is popular in cultural studies after Foucault, emphasizing that a subject is never an individual accomplishment but is always a compromised process of articulating a subject position against-and-with others. ${ }^{5}$ Thus the power to be a subject is

3 Scott Kugle is an American Muslim scholar whose writing on progressive Islamic issues engages both an Islamic worldview and secular discourses of human rights; for an explanation of his religious perspective, see Kugle, 'Sexual Diversity in Islam' in Vincent Cornell, Gray Henry and Omid Safi (eds.), Voices of Islam, New York, Praeger Press 2007, vol. 5, 131-168.

4 Stephen Hunt, 'Saints and Sinners: The Role of Conservative Christian Pressure Groups in the Christian Gay Debate in the UK', in Sociological Research Online 8:4 (2003), http://www.socresonline.org.uk/8/4/hunt.html. See also Hunt, Alternative Religions: A Sociological Introduction, London, Ashgate Publishing 2003 and Religion in Western Society: Sociology for a Changing World, New York: Palgrave Macmillan 2002.

5 Foucault stresses that subjectivity is not a private space of self-understanding and asserts that it is formed in response to formative practices, social constraints and moral codes that exist prior to the individual, such that subjectivity is best understood as a modality of power. With regards to religion and ethics, Foucault defines moral subjectivization as the process of 'developing relationships with the self, for selfreflection, self-knowledge, self-examination, for the decipherment of the self by oneself, for the transformations that one seeks to accomplish with oneself as object'; 
not natural and inevitable, rather it must be projected. The male subject's power is projected as autonomous and authoritative, capable of subjecting others to its power as objects. The subject demands an object and the patriarchal masculine subject finds its primary object in women. Furthermore, this binary differentiation creates a range of other persons who are objects of its power: male youths (those yet to become men), slaves (those who are un-manned by being owned) and servants (those of a compromised masculinity who are rented). ${ }^{6}$

In psychoanalysis, 'abjection' means throwing out something integral to the subject. Abjection by a patriarchal male subject is the denial, rejection and suppression of the internal feminine integral to his personality. In patriarchal social systems, empowered men abject those qualities of their personalities which are perceived to be feminine. These qualities are projected onto women who, as objects, can be controlled. Yet the trace of these qualities still inheres within men, forcefully suppressed to sustain projections of masculinity and male power. ${ }^{7}$ It follows that nonheterosexuality is perceived as a threat to masculine authority when either women or men choose not to engage in reproductive sex since it questions the inevitability of patriarchal imperatives, revealing their fragility. Confronted by these behaviours, the upholders of patriarchy imagine that the family will dissolve, society collapse, morality disintegrate and human reproduction terminate. Such perceptions illustrate the irrationality of homophobia.

In patriarchal societies, masculinity is not merely a description of male persons. From a micro viewpoint, the masculinized cultural body is condensed into the erect phallus, perceived to represent the idealized male. From a macro perspective, the masculinized body is expanded to comprehend society as a totality, often projecting masculinity onto divine authority. God is imagined as a male being or a supernatural force with masculine qualities. Although Islam rebelled against nature deities, rejecting the imagination of divinity in human form, Muslim theologians

see Michel Foucault, The Uses of Pleasure. Volume 2 of The History of Sexuality, New York: Vintage Books 1990, 29.

6 Studies of power hierarchies that affect masculinity include Frédérick Legrange, 'Male Homosexuality in Modern Arabic Literature' and Emma Sinclair-Webb, 'Our Bülent is Now a Commando: Military Service and Manhood in Turkey' in Mai Ghoussoub and Emma Sinclair-Webb (eds.), Imagined Masculinities: Male Identity and Culture in the Modern Middle East, London: Saqi Books 2000.

7 Durre S. Ahmed, 'Gender and Islamic Spirituality: a psychological view of low fundamentalism' in Lahoucine Ouzgane (ed.), Islamic Masculinities, London: Zed Books 2006, 15. 
and jurists persisted in assuming that God was masculine. If this assertion was not made directly because to do so would contravene the Qur'an itself, it was made indirectly by denying feminine characteristics to God, claiming God upholds the empowering of men over women in a patriarchal Islamic social order. Some medieval Sufis questioned this patriarchal consensus and some contemporary progressive Muslims reject it. ${ }^{8}$ This has great impact on the heated debate in global media about the status and condition of homosexuals in Muslim communities. In turn, this has sparked an intra-Muslim deliberation regarding the Islamic norms (based on texts) and traditions (based on historical precedence).

Most spokespersons for an 'Islamic' position regarding homosexuals have been conservative or reactionary leaders, often with backgrounds in Islamist groups with an aggressive agenda to defend Islam against perceived threats. One such spokesperson is Shaykh Yusuf al-Qaradawi, an Islamic scholar respected by Sunni communities internationally and especially among Muslim minorities in Europe. This article analyses alQaradawi's discourse against sexuality minorities in his TV talk show. His programme serves as an example of 'Neo-traditionalist' Islamic narratives purporting to defend Islam as a tradition within a modern context and in doing so sometimes violates traditional Islamic teachings. The article aims to show how al-Qaradawi's discourse against homosexuality is actually an aggressive retrenchment of patriarchal masculinity, refusing dialogue with Muslim homosexuals, denying homosexuality as a cultural construct, and subsequently eliding homosexuals and their experience as members of the Islamic community.

\section{Shaykh al-Qaradawi and his Transnational Context}

Shaykh al-Qaradawi is a familiar figure to many contemporary Muslims. He was born in Syria, trained in theology and law at al-Azhar in Cairo, and became a member of the Islamic Brotherhood (al-Ikhwan al-Muslimin). On emigrating from Egypt to Qatar, he became an ideologue of the Islamic Movement. He is now considered one of the most respected Sunni scholars, supporting and directing the European Council for Fatwa and Research. ${ }^{9}$ Its stated goal is pronouncing fatwas promoting 'integration

8 On Sufis who question patriarchy, see Sa'diyya Shaikh, Sufi Narratives of Intimacy: Ibn Arabi, Gender and Sexuality, Chapel Hill: University of North Carolina 2012. On contemporary progressive rejections of patriarchy, see Omid Safi (ed.), Progressive Muslims: on Gender, Justice and Pluralism, Oxford: Oneworld 2003.

9 The European Council for Fatwa and Research (al-Majlis al-Urubbi li'I-Ifta' wa'l-Buhuth) was formed in London in 1997 at the initiative of the Federation of Islamic 
without assimilation. ${ }^{10}$ By participating in this fatwa council, al-Qaradawi actively seeks to influence religious and political opinions of Muslim minorities living in Europe. His media exposure, through the TV programme al-Shari 'a wa'l-Hayat, broadcast by Al Jazeera in Arabic, gives him wide reach into Muslim minorities globally. On this talk show a journalist elicits al-Qaradawi's authoritative opinion about various social issues, and then opens up a discussion with call-in audiences in a style adopted from Christian televangelists in North America which combines conservative social criticism with fundamentalist piety.

Since 1990, many support groups for homosexual Muslims have formed in European and North American nations. ${ }^{11}$ These groups form a loose transnational network that advocates basic rights of gay and lesbian Muslims in terms of health, welfare, legal rights and dignity within their religious community. ${ }^{12}$ Some members call for reconciling homosexuality with being Muslim in their identity formation, but not all members accept that reconciliation is possible. These groups make a strategic distinction between sexual orientation, sexual identity and sexual acts, a distinction which is important to their activist work to promote the rights and welfare of sexuality and gender minorities who are stigmatized and often persecuted in their Muslim community. The support groups assist those from Muslim families who identify as gay, lesbian, bisexual, transgender or queer. Because sexuality minorities are demographically small in any one religious community, these groups ally with non-Muslim progressive political groups, feminist groups, and advocates of homosexual rights. This makes them appear all the more threatening to Neo-traditionalists.

Neo-traditionalist Muslim spokespersons such as al-Qaradawi appeal to familiar patriarchal values, attempting to draw Muslims living in the West into an ideological antagonism toward homosexuals within their communities. In Neo-traditionalist forums, al-Qaradawi and his supporters, interviewers, and audience respond mainly to social stereotypes of homosexuals rather than engage with individuals from sexual minorities or

Organisations in Europe, which is mainly funded by the Maktoum Charity Foundation, established by the royal family of Dubai.

10 The Council's fatwas are permissive in certain economic and social spheres, encouraging Muslims to take mortgages under certain conditions, to consume certain meat products slaughtered by Christians or Jews, to bury Muslim dead in non-Islamic cemeteries, and to recognize civil marriages and divorces as Islamically valid.

11 Scott Kugle, 'Introduction', in Homosexuality in Islam: Critical Reflection on Gay, Lesbian and Transgender Muslims, Oxford: Oneworld 2010.

12 Scott Kugle, Voices of Gay, Lesbian and Transgender Muslims, New York: New York University Press forthcoming. 
their mobilized support groups. The TV programme analysed below is an example of this as it ignores gay and lesbian Muslims' voices and support groups. At least one of these activists has published his experiences in Arabic, yet al-Qaradawi gives no evidence of having read it. ${ }^{13}$

\section{Understanding Terms: Homosexual and Neo-Traditional}

From among the spectrum of sexuality and gender identities, this article deals primarily with homosexual Muslims - gay men and lesbian women. Gay is understood to mean men who identify as male and feel sexual attraction to other males in a predominantly exclusive way. Similarly lesbian means women who identify as female and feel sexual attraction to other females in a predominantly exclusive way. These categories are defined by sexual orientation and are independent of actual sexual acts. Persons who feel such a sexual orientation may act upon it or not, without actions affecting their orientation. Such persons may accept such a sexual orientation as part of their personality or repress it, and levels of acceptance are certainly affected by family relations, culture and religion, political system and legal rights. Those who accept homosexual orientation as part of their personality may integrate this into their identity by finding common ground with others who similarly identify, and the terms lesbian and gay have developed in the West as labels for these sexual identities, labels which are not inherently pejorative. But not everyone who accepts homosexual orientation as part of their personality necessarily identifies with it positively, for some may accept it as an ailment to be cured or sin to be repented. Those who integrate it into their identity and do not think it possible or necessary to change it may still encounter serious resistance from family, community, and religious tradition and thus choose to hide their orientation and lead covert lives, compromising with patriarchal expectations of family and community. Or they may find ways of living positive and productive lives by struggling with family and community or leaving them behind.

This is the scheme of sexuality that is used in this study. Desire, feeling, acts and identities are mutually related but not pre-determined. This study focuses on homosexual Muslims for two reasons. First, these are clearly defined sexuality identities that are easy to categorize and are popularly known. Secondly, these are the categories that many religious

13 Muhammad Omar Nahas, Al-Junusiyya: nahwa namudhaj li-tafsir al-junusiyya [Homosexuality: toward a method for interpreting homosexuality from the perspective of a Muslim homosexual man], Roermond NL: Arabica 1997. 
leaders have in mind when denouncing 'sexual deviants', including the Muslim scholar and media spokesperson analysed here. This article is dedicated to analysing and critiquing al-Qaradawi's denunciation of homosexual Muslims, as an example of a much wider phenomenon of Neotraditional Islamic discourse. For this reason, it will not reference the academic discussion whether homosexuality as defined above is an essential category or a constructed one. To those Muslims who take risks to debate about homosexuality -in an environment where the tone is set by leaders such as al-Qaradawi - the category 'homosexual' is an essential one. It organizes their feelings and experiences into a category upon which to base advocating recognition, welfare, rights and justice. Whether homosexuality is an essentially universal category in social history is another question, one largely irrelevant to those engaged in political and religious debate. ${ }^{14}$

The question whether homosexuality is essential or constructed has spilled much ink in the nascent field of sexuality studies. University careers have been founded upon taking a side and so it has been a productive question, at least in terms of academic discourse. But the academic debate has moved far away from the practical concerns of activists, legal experts and religious leaders. Sexuality studies have been dominated by intellectuals upholding queer theory during the ascendancy of postmodernism, intellectuals who have led the charge against any perceived essentialism. They disparage an earlier generation of feminist and homosexual scholarship for reifying these categories as essential, while positing that all such categories are in fact socially constructed. John Boswell was the most eloquent spokesperson for the so-called essentialist position with his research on homosexuality in medieval Christendom, and he is supported after his untimely death by Bernadette Brooten's scholarship on female sexuality in the late antique Mediterranean. ${ }^{15}$ The

${ }^{14}$ In the West, legal scholars have noted the elitism of academic debates about sexuality, sexual orientation and 'queer theory'. See Daniel Ortiz, 'Creating Controversy: Essentialism and Constructivism and the Politics of Gay Identity,' Virginia Law Review 79/7 Symposium on Sexual Orientation and the Law (Oct. 1993), 1833-1857; and Carlos Ball, 'Essentialism and Universalism in Gay Rights Philosophy: Liberalism Meets Queer Theory', Law and Social Inquiry 26:1 (2001), 271-293.

15 See John Boswell, Christianity, Social Tolerance, and Homosexuality: Gay People in Western Europe from the Beginning of the Christian Era to the Fourteenth Century, Chicago: University of Chicago Press 1980 and Same-Sex Unions in Pre-Modern Europe, New York: Vintage Books 1995; see also Bernadette Brooten, Love Between Women: Early Christian Responses to Female Homoeroticism, Chicago: University of Chicago Press 1996. 
constructivist charge was led eloquently by David Halperin, who has significantly softened his views over the course of debate. ${ }^{16}$ Consensus seems to be emerging that the debate is getting rather tired and academic careers are turning elsewhere. Essentialism of the 1970s and 1980s - with slogans such as 'gays are everywhere' - is overly romantic, too boldly universalizing and certainly elided all historical context. Yet constructivism of the 1990s was perhaps too obsessed with words and names and not concerned enough with performative gestures that have comparative value and historical continuity. ${ }^{17}$ In current sexuality studies, there are no absolute essentialists and few adamant constructivists. ${ }^{18}$ Scholars must be reminded that as long as society is organized by patriarchy, the essentialisms that are empowered are those that support heteronormativity and reinforce homophobia and transphobia. ${ }^{19}$

Just as categories and neologisms are important to the study of sexuality, the refining of terms and descriptors is important also to the study of Islamic movements. This is especially true in the contemporary environment, where Muslims' reactions to modernity are highly varied and all labels can be contested by those labelled. This article labels Shaykh alQaradawi as a Neo-traditionalist Muslim leader. This term requires explanation, especially because al-Qaradawi has been described with other labels, across the spectrum of 'Islamic Scholar' ('alim), 'fundamentalist', 'Islamist' and 'supporter of terrorist organizations.' Among these contradictory and often overtly politicized labels, Neo-traditional better describes his religious ideology in a more neutral and more analytical way.

${ }^{16}$ David Halperin, How To Do the History of Homosexuality, Chicago: University of Chicago Press 2002 and One Hundred Years of Homosexuality: and Other Essays on Greek Love, New York: Routledge 1990.

17 R. Halwani, 'Essentialism, Social Constructionism, and the History of Homosexuality', Journal of Homosexuality 35:1 (1998), 25-51.

18 John Boswell, 'Concepts, Experience and Sexuality', in E. Stein (ed.), Forms of Desire, New York: Routledge 1992 is an insightful assertion of consensus from the scholar who helped spark the debate.

19 Recent psychological research has turned attention to the negative essentialism of dehumanizing views of homosexuality that fuel continuing prejudice and discrimination; see Nick Haslam and Sheri Levy, 'Essentialist Beliefs About Homosexuality: Structure and Implications for Prejudice', Personality and Social Psychology Bulletin 32:4 (2006), 471-485. Sociological research has also tried to gauge the strength of homophobia among Muslims against social, economic, educational, and religious factors; see Tilo Beckers, 'Islam and the Acceptance of Homosexuality: the shortage of socioeconomic well-being and responsive democracy', in Samar Habib (ed.), Islam and Homosexuality, Santa Barbara: Greenwood Publishing Group 2010, vol. 1, 5795. 
In the mid-twentieth century, social scientists observed that populations in the formerly colonized world were divided between 'traditional' people and 'modernists'. In this view, modernists embraced Western political norms, educational institutions and cultural patterns while traditional people remained mired in the past. Traditional people clung to their religions and folkways, while modernists preached social reform, promoted economic prosperity (whether in capitalist, socialist or communist forms) and drifted inexorably toward secularism. Governments of newly decolonized states were run primarily by the modernists, who mimicked and displaced the former colonial powers. Some in formerly colonized regions began to criticize this governing system, critiquing the value of modernity; they can be labelled 'traditionalist' because they preached a return to tradition in terms of religion or ethnic culture in reaction to modernity. But of course, no one in the present can simply return to practise tradition of the past. Return to tradition is always selective, especially in times of rapid social and political change. ${ }^{20}$

In the context of Islamic societies, change was radical in the late 1970s. Opposition to ruling elites began to take the form of an aggressive ideology based in religious politics. The context for this shift was the Shiite Revolution in Iran, and the coup of the Sunni general Zia ul-Haqq in Pakistan, the resurgence of the Sunni Hamas and the Shiite Hizbullah militant organizations against Israeli occupation in Palestine, the religious assassination of President Anwar Sadat in Egypt, and the rise of petrodollar politics in the Wahhabi kingdom of Saudi Arabia and its tiny Gulf allies. Western social scientists and journalists called this new brand of religious politics 'fundamentalist'. This was a rather crude application of a term familiar to Protestant Christians in North America. But it did not have much analytical specificity, since the issues that drove the Protestant fundamentalist movement in America were hardly similar to those driving the Islamic fundamentalist movements listed above. Fundamentalist became a simply pejorative rather than a substantive term, although some scholars like Bruce Lawrence tried to refine its use as an intellectually sound comparative term. ${ }^{21}$

In reaction to the crudeness of the term fundamentalist, some scholars and journalists began to use the term Islamist. Islamism means an

${ }^{20}$ Ibrahim Abu-Rabi', 'Islamic Resurgence and the 'Problematic of Tradition' in the Modern Arab World: the Contemporary Academic Debate', Islamic Studies 34:1 (1995), 43-66.

${ }^{21}$ Bruce Lawrence, Defenders of God: the Fundamentalist Revolt Against the Modern World, San Francisco: Harper and Row 1989. 
ideology that portrays adherence to Islam as the solution to contemporary political crises. Islamism was first used in Francophone regions to describe Muslim political activists with such an ideology. Their use of Islam was more of a slogan than a substantive tradition, and they often differed radically among themselves as to what kind of Islam should actually be practised. But such differences were muted by their positioning of 'adherence to Islam' as an oppositional stance against a corrupt neocolonial elite, Western domination, and Israeli occupation. Such groups used slogans like 'The Qur'an is our constitution' or 'Islam is the answer' to each crisis of governance. Islamism in many ways was an improvement over fundamentalism, yet it is also ambiguous. ${ }^{22}$ For all Islamists, adherence to Islam as political rebellion may be the answer to political crises, but what kind of Islam is advocated and how will it be applied to politics? The term Islamism is too broad to specify the many varieties of ideological movements that occupy the category. Islamists could be Sunni or Shiite, militant or reformist, rejecting Western state institutions or accepting them, dismissive toward elections and legislatures or adaptive for their own ends. Contrasting examples are Muslim Brotherhood and the Taliban, both of which are Sunni Islamist movements. The Brotherhood (to which al-Qaradawi belonged) is reformist in orientation (though it had a secret militia) adapting electoral politics, building a women's wing, and adopting secular education and scientific discourse in its drive for political power. In contrast, the Taliban in Afghanistan is openly militant rejecting electoral politics, decrying secular legislatures, denying women any participation in public life, and attacking secular education.

Because of the wide variety of movements included under the term 'Islamist', many scholars prefer to name specific movements. The term Islamist includes the militant Wahhabis, and the Salafis, a reformist movement in Egypt, Syria and other Arab nations that began as an intellectual and devotional movement but inspired more radical militant offshoots like that which assassinated Sadat. It also includes the recent alQai'da movement and Shiite movements as dissimilar as the Iranian revolutionary government, the Iraqi opposition party of Moqtada al-Sadr and the Hizbullah militia in Lebanon. All these groups advocate adherence to Islam as a solution to political crises and are therefore Islamist, but the kind of Islam advocated and the style of advocacy are radically different. Yet doing social analysis using only the names of specific movements is

22 Martin Kramer, 'Coming to Terms: Fundamentalists or Islamists?', Middle East Quarterly 10:2 (2003), 65-77, summarizes political science debates over these terms for Islamic ideological movements. 
sometimes too narrow. They are linked to particular regions or formations rather than to the ideological content of the movement. Complicating this issue is the fact that in the early 21st century there are now Muslim immigrants and converts living in Western nations. Some of them support or sympathize with an Islamist movement without actually belonging to the movement or using its name, perhaps as a self-conscious distancing from the politics of a regional group or perhaps out of discretion in avoiding association with a group deemed 'terrorist' by Western governments under which they live. In this context, 'Neo-traditional' is a new term of analysis that is useful. ${ }^{23}$

'Neo-traditional' is a term that specifies the content of a movement and describes its discursive style. Neo-traditionalists advocate adherence to Islam as a solution for all social problems and personal ailments. They advocate this in opposition to a perceived threat of secular life, but they do not necessarily subscribe to a political movement, opposition party or militant rebellion. Neo-traditionalists articulate an ideology of defending Islam against assault by outside forces, but are ambivalent about supporting a particular tradition of Islamic practice from the past. They often are selective about what elements of the past Islamic tradition to advocate for the present, and adapt scientific and technological discourse to their defence of Islam. The authoritarian streak in 'Neo-traditional' discourse is often underplayed or hidden in order to appeal to modern or secular audiences and to distance the discourse from the polities of particular Islamist movements and their regional militancy or local tactical compromises. $^{24}$ In the decade after the September 11 attack, the term 'Neo-traditional' is increasingly used as a contrast to 'progressive' Muslims. The two groups share many elements of ideological approach, but differ over issues of authoritarianism, secular values, openness to change, and acceptance of commonalities with other religious groups. ${ }^{25}$

${ }^{23}$ Abdelwahab El-Affendi, 'The People on the Edge: Religious Reform and the Burden of the Western Muslim Intellectual', Harvard Middle Eastern and Islamic Review 8 (2009), 19-50, uses a slightly wider definition of 'Neo-traditional' than this article does in his analysis of the ideological positions of Muslim converts from the West.

24 Khaled Abou el Fadl, 'Islamic Authority', in Vogt et al (eds.), New Directions in Islamic Thought: Exploring Reform and Muslim Tradition, London: I.B. Tauris 2009, 129-44; and also Abou el-Fadl, And God Knows the Soldiers: the authoritative and the authoritarian in Islamic discourses, Lanham, MD: University of America Press 2001.

25 Adis Duderija, Constructing a Religiously Ideal 'Believer' and 'Woman' in Islam: NeoTraditional Salafi and Progressive Muslims' Methods of Interpretation, New York: Palgrave Press (Series in Islamic Theology and Law) 2011; for a case study situated in 
This article argues that Shaykh Yusuf al-Qaradawi articulates a 'Neotraditional' approach to Islam and that denunciation of homosexuality is an important element to his Neo-traditional Islamic discourse (though certainly not the only or primary element to it). He acts as an articulate and media-savvy spokesperson for Neo-traditional discourse with a transnational Islamic audience. He was trained as a Muslim jurist but he does not speak for any discrete 'school of law' from the past. He holds the status as a Muslim scholar ('alim) but he does not hold a position in any madrasa, a traditional institution for giving fatwas, or seminary. He claims authenticity as an Arab Muslim but for most of his mature career he lived outside the Arab nations (like Egypt, Syria and other populous nations beyond the Gulf) that house his primary audience. ${ }^{26}$ Finally, he selfconsciously crafts his discourse to serve as a model for Muslim immigrants and converts living in Europe and North America, highlighting his engagement with modern technology, digital media, and scientific or medical discourse.

\section{Al-Qaradawi's Pronouncements on Homosexuality}

Western psychiatry has come to accept same-sex attraction as a 'natural' disposition and that non-heterosexual people should act in accordance with their constitutional disposition. In contrast, the TV programme under analysis begins with the journalist host, Abd al-Samad Nasir, saying: 'God most glorious and exalted says in the divine message ... [This is] the nature (fitra) of God upon which people are created. There is no changing the creation of God' (Qur'an 30:30). The host then asks for Shaykh alQaradawi's response, structured by specific questions which pit Islam and Qur'anic verses against Western secularism and opinions of medical professionals. Al-Qaradawi answers by referring to divine authority and human nature whereby God creates all people as clearly gendered, female or male, for the purposes of reproduction and patriarchal social order. In his view, this order is both divinely ordained and natural, but it is threatened with disruption by sinful desire of individual Muslims and organized domination by Western secularity. Homosexuality is a part of this threat. In this view, homosexuality is an individual perversion, social

the Arabian Gulf, see Staci Strobl, 'Progressive or Neo-Traditional?: Policewomen in Gulf Cooperation Council (GCC) Countries', Feminist Formations 22/3 (2010), 51-74.

Since the uprising of 2011-12 and ouster of Hosni Mubarak, al-Qaradawi returned to Egypt to give public speeches and encourage the Muslim Brotherhood to succeed in elections; the political situation is still volatile and al-Qaradawi seems to be retaining his residency in Qatar. 
sickness and a discursive weapon used by Western forces guised as human rights or medical science. The host also presses al-Qaradawi to make pronouncements about the spread of HIV/AIDS, whether it is linked to homosexuality and if it can be considered divine punishment against homosexuals or societies that tolerate them. The host then asks alQaradawi to give an Islamic position on transgender issues but in such a way as to suggest that they are integrally linked to homosexuality. The analysis below focuses on al-Qaradawi's discussion of homosexuality rather than AIDS or transgender issues, although in his view these are all linked. The analysis is based upon Kugle's translation into English from an Arabic transcript of extracts of the TV programme posted by Al Jazeera on the Internet. ${ }^{27}$

Shaykh al-Qaradawi's pronouncements on the programme do not constitute a formal fatwa, but nonetheless carry great weight for contemporary Sunni Muslims. His pronouncements are biased by Arab cultural prejudices, provide a very narrow reading of the Islamic tradition, and display no comprehension of current medical and psychiatric research. Moreover, al-Qaradawi's pronouncement reveals no appreciation of what homosexuality means as a cultural construct. In Arabic, the concept is translated as al-jinsiyya al-mithliyya ('same-oriented sexuality'). Yet he collapses sodomy with homosexuality, failing to see that sodomy is a sex act referring to anal penetrative intercourse and homosexuality a disposition denoting same-sex attraction. In short, al-Qaradawi fails to recognize that homosexuality does not imply any particular sexual act which might express such an orientation. His interviewer asked alQaradawi: 'How should a homosexual man or a lesbian be punished?' He answered, 'The same punishment as any sexual pervert - the same as the fornicator ... The important thing is to treat this act as a crime.' Clearly, he confuses the homosexual with a form of sex-act; this is logically inadmissible. To ask what behaviour would be acceptable for a Muslim homosexual is a different question, to which there is a variety of opinions. Al-Qaradawi dismisses scientific research on homosexuality as merely a reflection of Western cultural attitudes, saying:

27 The transcript was transcribed to counter an abridged and biased partial translation that was posted on the Internet by MEMRI (Middle East Media Research Institute): see www.memritv.org/clip transcript/en/1170.htm (Clip No. 1170 posted on 5 June 2006).

The full Arabic transcription from which Kugle's English translation was rendered is available at www.aljazeera.net/programs/pages/db4c4a9f-7a04-4acc-8188-

92e1ba41a03c (accessed 12 July 2012). 
It is totally reprehensible of so many of our scientific scholars and medical doctors that they submit to the Western culture that is dominating the whole world. Westerners want to justify what is happening among them. It is a shame that so many scientific opinions are suspect ... What is publicly known about these [the positions of the World Health Organization] is that it is their desire to market and sell by trickery a new culture that wants to make this matter seem natural, to attribute it to nature.

By injecting themes of Western domination and cultural imperialism, alQaradawi thus downplays the relevance of contemporary medical research and psychiatric practice from debate around homosexuality.

During the TV show a doctor called for a phone interview and discussed how the consensus on defining and diagnosing mental illnesses is formalized in medical manuals, such as The Diagnostic and Statistical Manual of Mental Disorders. He noted that the American manual long ago removed homosexuality from its list of mental disorders, yet the Egyptian manual retains homosexuality as a mental illness in its latest publication (1979). The doctor also mentioned that the issue is currently under debate as the Egyptian manual is regularly updated and revised, and that the World Health Organization frequently intervenes to urge all nations to update their clinical manuals (like all medical practices) to meet the highest standards and incorporate the latest developments.

Throughout this nuanced discussion, the host of the show, along with Shaykh al-Qaradawi, continually interrupted the doctor who was finally cut off when he expressed his clinical assessment that sexual behaviour can change through psychiatric treatment but not sexual orientation. Al-Qaradawi then summarized in order to distort what was stated: 'At the end of the talk of our brother, Dr. al-Kharrat, he said that he cured some people of this homosexual attraction and healed them of this disease. So it can be cured and that means that it is a disease. The disease is a form of deviance (inhiraf).' Al-Qaradawi thereby denies the concept of sexual orientation (jinsiyya) as an integral part of an individual's personality. He asserts instead there is only sexual attraction (muyul). Attraction can be normal or can be deviant, and deviant attraction leads to behaviour that is sinful (in God's view) and criminal (in society's assessment).

\section{Shaykh al-Qaradawi on Human Nature}

Dismissing the concept of sexual orientation is a way to deny that homosexuality occurs naturally and is part of God's creation. Rather, alQaradawi asserts that homosexuals' existence marks a deviation from God- 
given human nature. At the start of the TV programme, the host quoted the Qur'an to say, [This is] the nature of God upon which people are created (Qur'an 30:30). He later asked Shaykh al-Qaradawi, 'What is the meaning of 'nature' here?' Al-Qaradawi answers the question in this way:

The word 'nature' (fitra) is derived from the term for creation (al-fatr), as in the verse: All praise belongs to God, the creator (fatir) of the heavens and earth (Qur'an 35:1). It refers to the original nature with which each person is born that is not acquired or learned or attained; each and every person has it without entering school or being taught by parents or being effected by environment. Such things are natural things .... The human being is created with innate disposition to feel attraction to the other sex, with man attracted to woman and woman attracted.... I mean, this is a matter of biology (amr tabi ii) ... That is the meaning of 'nature.' The religion of Islam came to preserve the original human nature not to oppose this nature by rebelling against nature.

Al-Qaradawi thus equates an innate disposition to believe in God with an innate heterosexual orientation, making homosexuality a form of kufr or infidelity. He then moves on to discuss Christian monasticism, Manichean asceticism and Kantian relativism in a challenge to what he sees as the basis of Western civilization.

The TV host realizes that his audience is not interested in philosophy. It would rather hear a fatwa on how to treat homosexuals in their communities. So he insists on asking:

But the intent of my question was this, most honorable Shaykh - perhaps the most dangerous, I mean the worst, aspect of alteration and deviation from human nature which affects it in our era - especially because it is becoming open and public - is sodomy (liwat) and tribadism (sihaq). We can notice that these practices have become legalized. There have become sources of national law that consider sodomy and tribadism among basic human rights (huquq al-insan). And in Muslim communities lately we see how some of these institutes and organizations that have been formed by Sodomites (liwatiyyin) and Tribads (sihaqiyyin) have begun public activity and open movement. They have started demanding what are called their so-called human rights. So what, in short, is the view of the sharia on sodomy and tribadism?

To this specific question, al-Qaradawi reiterates his views on natural heterosexuality strengthened by his view on bimorphic gender.

God created the human being as male and female... so natural attraction is between the two sexes, because the Qur'an mentions that this cosmos is based upon pairing (izdiwaj) not upon sameness (mithliya). The principle of 
mating (zawjiya) is the principle of the cosmos: Glory be to the One who creates all the pairs, from what grows in the earth and from among yourselves and from that of which you know not (Qur'an 36:36).

Neo-traditionalists like al-Qaradawi have moved far from the intellectual vision of classical era Muslim thinkers. Ibn Hazm, for instance, perceived that pairing happened owing to love, igniting when two souls found harmony between each other, forming an integral whole. He conceived of loving attraction happening between two men or two women identical to that of between a woman and a man. Ibn Hazm, the tenth-century jurist of Córdoba and prominent Arab intellectual, asserted that acting upon this love through sexual acts without a contract of marriage was a sin and a crime, but he admitted that love was involved, arising from forces deep within? one's personality. ${ }^{28}$ Al-Qaradawi leaves no room for love but merely purports a clinical view that pairing happens when male and female sexual organs come together rather like a plug in an electric socket.

Shaykh al-Qaradawi reduces the issue of sexual orientation to that of gender, expressed as an ideology shared by most Muslims who are raised in a patriarchal society and perpetuate it through their cultural assumptions. Patriarchy rests upon a definition of gender in which male is clearly and immutably separate from female, such that male mates only with female and the male needs to control female. What makes alQaradawi's position Neo-traditionalist, rather than merely conservative, is that he does not simply confirm this gender ideology, but does so through appeals to biology and physics. However, the Shaykh's knowledge of biology and physics is outdated, failing to appreciate that modern biology has discovered mating behaviour in many animal species is far more complex than patriarchal dichotomies between male and female.

The TV host plays devil's advocate by questioning al-Qaradawi's gender ideology. He says, 'I read recently, honorable Shaykh, that an Arab journalist writes that this sexual abnormality (al-shudhudh) is not a matter of choice but is rather an innate disposition with which the abnormal person (al-insan al-shadhdh) has been created.' Al-Qaradawi answers, 'Such talk is unbelievable! If a man were to be content with [sexually desiring other males] then why did his Lord create him with male reproductive organs? I mean, the man was not made to be like the woman!' To clarify the issue, the TV host asks him, 'The American

${ }^{28}$ Camilla Adang, 'Ibn Hazm on Homosexuality: a Case-Study of Zahiri Legal Methodology', Al-Qantara XXIV:1 (2003), 5-31. 
professional association of psychiatrists has removed sodomy and tribadism as sexual deviance - as it is still believed by many - and labelled them simply a human variation of sexual practice ... Honorable Shaykh, is this practice of sexual abnormality an innate disposition or a moral character?' He answers categorically, 'No, this is absolutely not an innate disposition (khilqa) - it is contrary to the original human nature (al-fitra).'

\section{Consequences of Homosexuality}

The TV host noted there are gay and lesbian organizations in the West and also in Muslim communities asserting homosexual human rights, and that some religious organizations accept this. Shaykh al-Qaradawi answers, 'Even if there are some persons who have left their original nature and engage in this practice, then this is, I regret to say, a decline in human value.' If homosexuals are 'declined in human value' then coercion against them is justified both for the social good and as a religious duty. The programme host asked al-Qaradawi to elaborate on what punishments are required for those who are no longer fully human. Predictably, al-Qaradawi cites the narrative of Lot as found both in the Torah and the Qur'an. In his interpretation, God destroyed Lot's tribe because of their homosexual acts (or acceptance of them in neighbours and family) and Muslim jurists simply follow this precedent.

Gay and lesbian Muslim activists counter this conventional interpretation by arguing that the people of Sodom and Gomorrah were not destroyed due to homosexuality or same-sex acts. Rather they were destroyed because of their infidelity, just like all other ancient peoples destroyed by miraculous disasters cited by Torah and Qur'an. Before any sexual act has been perpetrated, these people were infidels who denied worship of one God and dismissed the authority of Prophets sent to call them to reform. ${ }^{29}$ The Qur'an cites many types of crime or immoral behaviour that express an attitude of infidelity, especially in the abuse of vulnerable wayfarers. ${ }^{30}$ These activists stress that the sex acts perpetrated in the narrative constitute rape which happens to be male-on-male. Rape rather than sexual orientation is the issue, specifically when the abusers try to rape those wayfarers whom the Prophet Lot has taken under his

${ }^{29}$ Scott Kugle, 'Sexuality and Sexual Ethics in the Agenda of Progressive Muslims' in Omid Safi (ed.), Progressive Muslims: on Gender, Justice and Pluralism, Oxford: Oneworld 2003, 203-15.

30 Jamel Amreen, 'The Story of Lut and the Qur'an's Perception of the Morality of SameSex Sexuality', Journal of Homosexuality 41:1 (2001), 1-88. 
protection and hospitality, as a way to deny his authority, expelling him from their towns.

There has always been room for differing interpretation of the Qur'an, as well attested by the many shelves occupied by tafsir or exegetical literature. In fact, past Muslim jurists did not base their decisions upon this narrative of the Prophet Lot. There are several obstacles to doing so. First is the general assumption that the legal systems brought by past prophets are abrogated in the Islamic dispensation. Second is the problem that even if God destroyed the Sodomites for homosexual acts or orientation, the Qur'an does not explicitly demand Muslims do so; a singular act of God is not a legal command.

Muslim jurists turned to other sources for making legal decisions, such as precedent of earlier Muslims, hadith reports attributed to the Prophet Muhammad, and juridical analogy. Different legal schools came to different conclusions based upon these sources. Their divergence is too complex to discuss here in detail. Suffice to say Ibn Hazm analysed this divergence and found no consensus among legal schools in their decision on punishment of homosexual intercourse and no agreement in legal reasoning based upon religious sources. He noted the legal schools could only agree that homosexual intercourse was wrong and was punishable. In his analysis, the only reliable source was a Qur'anic verse saying Muslims must keep their genitals from intercourse with anyone with whom they do not have a contract; and in his era it was impossible for same-sex couples to have a contract of marriage or other legal relationship.

Shaykh al-Qaradawi knows these differences of legal opinion well, having studied Islamic jurisprudence. Yet he does not admit there is any difference of opinion. For him, the shari'a is clear and univocal. He follows the Shafi i school's decision and reasoning, downplaying other possibilities, and limits diversity of opinion among classical Islamic jurists. His ideological approach to the issue is informed by his Muslim Brotherhood background which advocates a uniform application of legal rules without allowing for traditional divergence of opinion. When asked by the TV host, 'How should a homosexual or a lesbian be punished?' he answers:

The same punishment as any sexual pervert... The schools of thought disagree about the punishment. Some say they should be punished like fornicators, and then we distinguish between married and unmarried men, and between married and unmarried women. Some say both should be punished the same way. Some say we should throw them from a high place like God did with the people of Sodom. Some say we should burn them and so on. There is disagreement. 
While he admits there is disagreement, he vastly limits its actual scope, most crucially avoiding admission of diversity of opinions among jurists arising from ambiguities of scriptural sources.

When one researches opinions offered by Muslim jurists from different eras and various legal schools, one finds disagreements among them that are wide and deep. ${ }^{31}$ Indeed, the issue can be considered open to contemporary ethical-legal analysis (ijtihad) and reconsideration rather than closed by juridical consensus of the past. This is the position of the medieval jurist Ibn Hazm: he strongly criticized jurists from other legal schools for making decisions which deprived fellow Muslims of life and welfare on the shaky basis of unreliable hadith reports or reports with only a single chain of narration. He observed that the Qur'an makes no explicit legal ruling on homosexual sex acts upon which Muslims are obliged to respond, leaving it up to ruler or state to devise punishment that keeps order according to need and circumstance, specifying that no punishment should exceed ten lashings. ${ }^{32}$ Contemporary gay Muslim activists and scholars build upon his example, arguing that the Qur'an makes no explicit legal case against consensual male-with-male sex acts. In the case of samesex acts between two women, the issue is far more ambiguous. No verse in the Qur'an clearly addresses the issue, neither in the narratives about the Prophet Lot nor in Surat al-Nisa, in contradistinction to the assertions of contemporary Neo-Traditionalist ideologues. Among classical jurists and Qur'an commentators, only a tiny minority claimed that the Qur'an discussed sex between two or more women. Islamic legal discussion in all schools of law is even more ambiguous when it comes to non-penetrative acts between same-sex couples.

Shaykh al-Qaradawi distinguishes between lesbianism and male homosexuality, disregarding the concept of sexual orientation. This is evident when the TV host asks him why classical Islamic law treats male-tomale intercourse differently than female-to-female intercourse: 'If homosexual men and lesbians belong to the same category - an inclination

${ }^{31}$ For a full discussion of divergence between the legal schools see Kugle, Homosexuality in Islam, chapter 4. Shafi i jurists ruled that same-sex male penetrative intercourse is analogous to penetrative intercourse between heterosexual partners without a valid contract. They relied on juridical reason (qiyas) and hadith reports in deciding the punishment should be stoning to death (if the perpetrator were mature and married) or lashing (if he were not yet mature or married), in parallel with the punishment for heterosexual fornication. This is the position Shaykh al-Qaradawi portrays as normative, though in fact it is only one option among many.

32 Ibn Hazm al-Andalusi, al-Muhalla bi'l-Athar, Beirut: Maktab al-Tijari 1960, vol. 11, topic 2299. 
towards the same sex - why are there different punishments for men and for women?' Al-Qaradawi does not understand the question: the meaning of the terms seems unclear to him. Yet he answers, 'Lesbianism is not as bad as homosexuality, in practical terms.' He imagines that since women lack a penis for penetrative intercourse and thus, 'in practical terms' they cannot really have sex, which he imagines to be defined as penile penetration. He asserts women are subordinate to men and therefore lesbian sexuality does not threaten the patriarchal status quo in the same way as gay male sexuality. His answer reveals that he is responding from a patriarchal male bias which is culturally encoded in his Arab background, rather than from a firm contemporary understanding of sexual orientation. In other ways, al-Qaradawi betrays traditional Islam in service to ideological Islamism. He does not distinguish between inner disposition and outer action which is a distinction essential to classical Islamic law, thus misrepresenting the positions of Islamic jurists, and gives an ideological or Neo-traditionalist response rather than honest assessment of the Islamic convention. To illustrate this problem, observe how the TV host asks al-Qaradawi, 'Should a man be punished for having homosexual tendencies?' to which he answered, 'Yes, he should.' The host presses him to clarify if the punishment was for a tendency or for a sex act by asking, 'Maybe he should be punished only for committing this sin?' Al-Qaradawi avoids any clarification of this crucial issue and answers, 'He should be punished just like a fornicator. What is fornication? It is a sexual perversion. A perversion cannot possibly be innate.'

\section{Execution and its Consequences}

In this TV programme, Shaykh al-Qaradawi asserts that a person who has homosexual tendencies should be punished like a fornicator that is guilty of heterosexual intercourse outside of marriage. By this, he means execution (if the perpetrator is of mature age). His statement commits fellow Muslims to death for a personality 'tendency' rather than for actual sexual acts. This is a gross violation of Islamic norms.

The Prophet's biography (sira) offers us no specific case in which he proposed punishment for any man or woman for homosexual acts, let alone homosexuality as a disposition or tendency. His followers did burn a man for 'doing the act of Lot's people' but it is not clear whether this was a result of same-sex intercourse or rebellion during the Ridda wars of 
apostasy. ${ }^{33}$ In any case, execution by burning is not accepted in Islamic law, so this case does not offer later Muslims a clear legal precedent for the death penalty which Shaykh al-Qaradawi advocates. Some hadith reports also command execution for homosexual intercourse, but these are all reports with single chains of transmission (hadith ahad) that may originate from the opinions of later generations of Muslims rather than 'authentically' transmitted teachings of the Prophet himself. More research by hadith experts is necessary to clarify this question before the blood of fellow Muslims is shed or their welfare threatened.

Al-Qaradawi's pronouncement was made in Qatar, an Arab nation and Muslim-majority country, where the death penalty for homosexual acts is state law. But his audience is much wider. His pronouncements are specifically made as guidance for Muslim minorities living in Europe and North America, where execution is not a legal punishment for any kind of homosexual act. Hence, his pronouncements may lead Muslims in the West to say or do things that are illegal, thereby endangering themselves and damaging their communities. His statement that Islam requires the execution of homosexuals can be assessed as 'hate speech' or 'inciting violence' in the context of Western democratic states which strong constitutional protection of individual rights. ${ }^{34}$

Al-Qaradawi is aware that his opinions and announcements are followed by Muslims in the West. He specifically sets himself up as articulating al-fiqh al-'aqalliyat or Islamic law for minorities living in nonIslamic environments. Neo-traditionalist Muslims' approaches to gender relations and sexual orientation create deep-set obstacles to citizenship under Western constitutions. In this sense, al-Qaradawi's pronouncements on homosexuality contradict explicit aims of Islamic institutions that he supports in the West, such as the European Council for Fatwa and Research. Its fatwas are permitted in certain economic and social spheres, but they tend to be restrictive in the family sphere of gender relations and sexual practices. Yet in Europe, as in the West in general, issues of gender and sexuality are not merely private; they are public since many countries offer legal protection against discrimination on the basis of sexual orientation and gender identity. In such countries, preaching hatred,

${ }^{33}$ Al-Qurtubi, Tafsir al-Jami' fi Ahkam al-Qur'an, vol. 7, 244, narrates this report as part of his juridical interpretation of Lot's story in Qur'an 7:80. See Kugle, Homosexuality in Islam, 136-45.

34 Gert Hekma, 'Imams and Homosexuality: a Post-gay Debate in the Netherlands', Sexualities 5:2 (2002), 237-48. 
violence or exclusion of lesbian and gay Muslims conflicts with civil law, and if taken to extremes amount to break one's contract of citizenship.

Al-Qaradawi's opinions, if followed by Muslims in many constitutional democracies, place them at risk of breaking the law, staining the reputation of the Islamic minority community and fueling anti-Muslim sentiment (which is already strong in many regions for reasons of religious chauvinism or racism). In Muslim minority communities such as in the West, for example, invoking the death penalty is a way for families and communities to justify other forms of oppression such as withholding support, locking up children or spouses in their homes, threatening them with violent reprisals, or in rare cases perpetrating 'honour killings'. In these circumstances, al-Qaradawi's rhetoric is reckless and unjust, inciting violence against fellow Muslims.

\section{Civic Values}

Shaykh al-Qaradawi aims to close down debate and scholarly discussion of this topic, and in a way that betrays the intellectual and moral confidence of the Islamic tradition. His interviewer asked him, 'Some Arab authors have begun to discuss this openly in newspapers and in books. Homosexual characters appear in some Arab films.... What is the position of Islamic law on this public display? ${ }^{35} \mathrm{He}$ answered:

This is a great calamity for all societies. It is a kind of rebellion against religion ( $m a$ `siya) and immorality (fahisha) that is not so injurious to society as long as people cover it up. In that case, it is a matter that society isolates and limits and it does not manifest openly. However, it becomes a plague (ba/wa) afflicting all whenever it gets out from under secrecy and enters public knowledge, from the narrow confines to the wide open space, where it is flaunted.... The real danger when people flaunt this matter openly is that 'everyone in my community is excused except those who publicize [their misdeeds]. The Qur'an says, Those who love that immoral scandal should circulate among those who believe shall have a grievous chastisement (Qur'an 24:19), so spreading scandalous immorality that is the great danger.

Al-Qaradawi here confuses two things: the public display of sex acts and the open discussion of sexuality as an issue of public concern. In the

${ }^{35}$ When the TV host comments on the portrayal of homosexuals in film and books, he probably had in mind the Egyptian film, The Yacoubian Building (released in June 2006, based on the novel by Alaa Al Aswany), which depicts a homosexual character in a highly stereotyped way. 
classical Islamic tradition, jurists and theologians were open to discussing almost all issues, including sex and sexuality. Many jurists were also poets and prose writers. Arabic poetry and literature is full of discussion and debate about homosexuality, making a clear distinction between same-sex love, same-sex erotic attraction and same-sex acts of sexual pleasure. It is only the later topic that was controversial. The same confident and open attitude is revealed in Persian, Urdu or Turkish literature, as revealed by a host of recent scholarly studies. ${ }^{36}$

To justify suppressing open discussion of homosexuality, alQaradawi's cites the verse Those who love that immoral scandal should circulate among those who believe shall have a grievous chastisement (Qur'an 24:19). But the verse he quotes is taken completely out of context for it has no relevance to homosexuality. That verse uses the term fahisha to refer to false accusation of adultery in the context of heterosexual intercourse. In this verse, the Qur'an addresses those who slandered the Prophet Muhammad's young wife ' $A$ 'isha to discredit him by attacking the reputation of his wife (Qur'an 24:4). This initiates a series of verses on false accusation, admonishing those who commit this sin, a discussion which persists through verse 24:20 including the verse quoted. Al-Qaradawi knows very well the direct reference of this verse, the incident inciting it, and the legal conclusion drawn from it in shari a. Yet he deliberately obscures this to apply the verse to discussion of homosexuality, to keep gay and lesbian Muslims from speaking out about their condition and to prevent other Muslims from making objective inquiry into the matter. AlQaradawi is not alone in this misapplication of a Qur'anic verse. Other NeoTraditionalists in North America have done the same in online fatwas against homosexual Muslims. ${ }^{37}$

${ }^{36}$ Examples include Khalid el-Rouayheb, Before Homosexuality in the Arab-Islamic World, Chicago: University of Chicago Press 2005; Walter Andrews and Mehmet Kalpakli, The Age of Beloveds: Love and the Beloved in Early-Modern Ottoman and European Culture and Society, Durham: Duke University Press 2005; and Ruth Vanita and Saleem Kidwai (eds.), Same-Sex Love in India: Readings from Literature and History, New York: St. Martin's Press 2000.

37 The IslamOnline website is influential in Muslim circles with its online fatwa service. It has an international scope, focusing on North America but with participation among Muslims who read English. Apparently, the application of verse 24:19 to suppressing homosexuality was first made by Dr. Muzammil Siddiqi (the former President of ISNA who is based in Chicago) who issued a fatwa over IslamOnline, entitled, 'Islamic Manners in Dealing with Homosexuals' on 18 June 2003. It was followed by Shaykh Ahmad Kutty (of the Islamic Institute of Toronto) who published a fatwa at Islam Online to answer the question 'Can I Attend a Homosexual 'Wedding'?' on 17 May 2004. 
Al-Qaradawi's pronouncement does not further a respectful or faith-based discussion of the topic. Homosexuality occurs in Muslim communities, in the Arab world as in the West. But his message is one of forced silence: 'We are not hostile towards these people. On the contrary, we pity them. But we do not want to give them an opportunity, like the Westerners who consider this a normal phenomenon.' This concession to compassion is disingenuous. Al-Qaradawi advocates execution based upon sexual orientation, so it is hard to believe him when he says 'we are not hostile to these people.' He justifies the current practice of executions in some few Muslim majority countries, encouraging the continued stifling of dignity and wellbeing of gay and lesbian Muslims elsewhere. This position is one of coercive hostility disguised as piety. Al-Qaradawi depicts an open discussion of Muslim homosexuals as 'promoting' homosexuality. The metaphor he uses is that of a virus. When asked about homosexuality being openly discussed in society, he answered, 'It [homosexuality] becomes the plague afflicting everyone whenever it gets out from under secrecy and enters public knowledge... Whoever is afflicted with this has a disease that we must certainly cure. We must not... open any doors for them... and if not... then our society is destroyed.'

\section{Conclusion}

This article has presented extracts from a TV programme in which Shaykh al-Qaradawi charts a Neo-Traditionalist response to homosexual Muslims. His response constitutes a media fatwa because many Muslims see him as a preeminent Sunni legal authority with Al-Azhar credentials. The analysis of his discourse shows how al-Qaradawi misrepresents homosexual Muslims: he misunderstands and distorts the basic concept of 'sexual orientation' and his defence of patriarchal masculinity. This demonstrates how fragile his discourse really is. In the effort to suppress Muslim homosexuals, he does injustice to the Islamic tradition he purportedly defends. He mutes disagreements inherent in the Islamic juridical tradition and distorts verses from the Qur'an. Al-Qaradawi's strategy advocates intolerance of homosexuals as an authentic expression of heightened loyalty to Islam in a contemporary transnational form based on Salafi ideals, to the point of advocating violence against them. His response constitutes an Islamically inflected homophobia.

This article has focused on al-Qaradawi because he is an eloquent spokesperson for Neo-traditionalists. His TV interview offers a convenient way to access their world-view. This analysis-and-rebuttal of his statements is not offered as a personal attack against him. Rather, it is intended as a 
challenge to the world-view he expresses. This article's sustained focus on al-Qaradawi does not imply he is unique. To the contrary, he expresses a position replicated by many agents in the media and in Muslim community interactions. In this sense, the position taken by al-Qaradawi is both normal and normative. It is normal in that many Muslims see it as expressing common sense; the prejudice he justifies and the stereotypes he reinforces are held by many as simple fact. It is normative in that many Muslims see al-Qaradawi as an authoritative guide; the over-simplifications he offers and the distortions he makes are accepted by many as rules to follow. His informal interviews on TV can have an impact on Muslim minority communities in the West, far from places where his urging execution could be actually carried out. Needless to say, they may also have a devastating impact on the everyday lived experiences of sexual minorities within them. 